\title{
PELAYANAN KESEHATAN PEDULI REMAJA (PKPR) DENGAN MENCIPTAKAN KONSELOR SEBAYA DI MAN DUMAI DAN SMKN 3 DUMAI
}

\author{
Salmiati $^{1)}$, Rini Hariani Ratih'1), Maria Arani ${ }^{1)}$ \\ 1)Program Studi D III Kebidanan Fakultas Kedokteran dan Ilmu Kesehatan \\ Universitas Abdurrab \\ Email :amysalmiati@gmail.com
}

\begin{abstract}
ABSTRAK
Remaja merupakan individu yang sedang mengalami masa peralihan, yang dari segi kematangan biologis, seksual sedang berangsur-angsur memperlihatkan karakteristik seks sekunder sampai mencapai kematangan seks.Berbagai permasalahan yang terjadi pada remaja dipengaruhi oleh berbagai dimensi kehidupan dalam diri mereka, baik dimensi biologis, kognitif, moral dan psikologis serta pengaruh dari lingkungan sekitar.Dalam mewujudkan remaja sehat, salah satu upaya pemerintah adalah dengan pembentukan Program Pelayanan Kesehatan Peduli Remaja (PKPR). Tujuan kegiatan pengabdian memberikan pelayanan kesehatan peduli remaja dengan diawali pemberian informasi dan edukasi melalui penyuluhan kemudian memberikan kesempatan bagi remaja yang berminat dan berbakat untuk mengikuti pelatihan pendidik sebaya dan konselor sebaya di sebuah ruangan tertutup. Metode pengabdian pada masyarakat ini dengan melakukan penyuluhan dan pelatihan untuk menjadi konselor remaja. Hasil dari pengabdian siswa sangat antusias dalam kegiatan tersebut dan ada beberapa siswa yang memiliki bakat menjadi konselor remaja. Dalam mewujudkan remaja sehat, salah satu upaya pemerintah adalah dengan pembentukan Program PKPR.Jenis kegiatan PKPR meliputi penyuluhan, pelayanan klinis medis termasuk pemeriksaan penunjang, konseling, pendidikan keterampilan hidup sehat (PKHS), pelatihan pendidik sebaya (yang diberi pelatihan menjadi kader kesehatan remaja) dan konselor sebaya (pendidik sebaya yang diberi tambahan pelatihan interpersonal relationship dan konseling), serta pelayanan rujukan.
\end{abstract}

Kata kunci: Pelayanan Kesehatan Peduli Remaja (PKPR), Konselor Remaja

\begin{abstract}
Adolescents are individuals who are undergoing a transitional period, which in terms of biological maturity, sexual being gradually show the characteristics of secondary sex until the maturity of sex. Various problems that occur in adolescents are influenced by various dimensions of life within them, both biological, cognitive, moral and psychological dimensions and the influence of the surrounding environment. In realizing healthy teenagers, one of the government's efforts is with the establishment of Youth Care Care Program (PKPR). The Purpose of Community Service Activity to Provide Care for Youth Care (PKPR) by providing information and education through counseling then provides an opportunity for interested and talented teenagers to attend peer educator training and peer counselors in a closed room. Methods of dedication to this community by doing counseling and training to become a teen counselor. The results of student devotion are very enthusiastic in the activity and there are some students who have the talent of being a teen counselor. In realizing healthy teenagers, one of the government's efforts is with the establishment of Youth Care Care Program (PKPR). Types of PKPR activities include counseling, medical clinical services including investigation, counseling, healthy life skills education (PKHS), peer educator training (trained into adolescent health cadres) and peer counselors (peer educators who are provided with additional interpersonal relationship and counseling training), as well as referral services.
\end{abstract}

Key words: Health Care for Youth Care (PKPR), Youth Counselor

DOI : https://doi.org/10.36341/jpm.v2i1.427

Some rights reserved BY-NC-SA 4.0 International Lic 


\section{PENDAHULUAN}

Remaja indonesia saat ini sedang mengalami perubahan sosial yang cepat dari masyarakat tradisional menuju masyarakat modern, yang juga mengubah norma-norma, nilai-nilai dan gaya hidup mereka. Remaja yang dahulu terjaga secara kuat oleh sistem keluarga, adat budaya serta nilai-nilai tradisional yang ada, telah mengalami pengikisan yang disebabkan oleh urbanisasi dan industrialisasi yang cepat. Hal ini diikuti pula oleh adanya revolusi media yang terbuka bagi keragaman gaya hidup dan pilihan karir. Berbagai hal tersebut mengakibatkan peningkatan kerentanan remaja terhadap berbagai macam penyakit, terutama yang berhubungan dengan kesehatan seksual dan reproduksi, termasuk ancaman yang meningkat terhadap HIV/AIDS [1]

Timbulnya masalah pada remaja disebabkan oleh berbagai faktor yang sangat kompleks. Secara garis besar, masalah kesehatan remaja dapat dibagi kedalam dua golongan yaitu masalah kesehatan fisik dan perilaku. Beberapa kesehatan fisik yang menjadi permasalahan pada remaja antara lain mulai munculnya jerawat, gangguan pada mata, pendengaran, dan masalah gizi . Dalam mewujudkan remaja sehat, salah satu upaya pemerintah adalah dengan pembentukan Program Pelayanan Kesehatan Peduli Remaja (PKPR)[1]

PKPR dilaksanakan di dalam gedung atau di luar gedung Puskesmas termasuk Poskestren, menjangkau kelompok remaja sekolah dan kelompok luar sekolah, seperti kelompok anak jalanan, karang taruna, remaja mesjid atau gereja, dan lain-lain yang dilaksanakan oleh petugas puskesmas atau petugas lain di institusi atau masyarakat. Jenis kegiatan PKPR meliputi penyuluhan, pelayanan klinis medis termasuk pemeriksaan penunjang, konseling, pendidikan keterampilan hidup sehat (PKHS), pelatihan pendidik sebaya (yang diberi pelatihan menjadi kader kesehatan remaja) dan konselor sebaya (pendidik sebaya yang diberi tambahan pelatihan interpersonal relationship dan konseling), serta pelayanan rujukan [2].

Koselor sebaya adalah anak remaja berasal dari sekolah (SMP/SMA/sederajat), karang taruna, poskestren, pemuda mesjid/gereja/keagamaan lainnya, pekerja industri, anak jalanan, dan lain-lain yang dilatih dengan materi tertentu sehingga mampu memberikan informasi dan ikut membantu menyelesaikan masalah kesehatan pada teman sebayanya. Apabila konselor sebaya menemukan masalah kesehatan, harus mampu merujuk masalah kesehatan tersebut ke fasilitas rujukan yang tersedia [2].

Tujuan dilakukan kegiatan pengabdian adalah memberikan Pelayanan Kesehatan Peduli Remaja (PKPR) dengan diawali pemberian informasi dan edukasi melalui penyuluhan kemudian memberikan kesempatan bagi remaja yang berminat dan berbakat untuk mengikuti pelatihan pendidik sebaya dan konselor sebaya di sebuah ruangan tertutup .

\section{BAHAN DAN METODE}

Pengabdian masarakat ini tertuju kepada siswa dengan tingkat umur remaja awal. Kegiatan ini di laksanakan di MAN Dumai dan SMKN 3 Dumai pada tanggal 10 dan 11 Maret 2017. Kegiatan dalam pengabdian ini diawali dengan melakukan penyuluhan serta kemudian melakukan pelatihan pendidik sebaya dan konselor sebaya. Diharapkan 
setelah mendapat pelatihan tersebut remaja bisa mengaplikasikan ilmunya kepada teman sebaya tentang masalah didunia remaja terutama masalah reproduksi pada remaja.

\section{HASIL DAN PEMBAHASAN}

Pelaksanaan kegiatan pengabdian masyarakat tidak ditemui kendala ataupun masalah, baik dari segi sarana maupun prasarana. Pada saat nara sumber menyampaikan seluruh materi penyuluhan, siswa-siswi terlihat fokus mendengarkan, begitu pula pada saat materi yang disampaikan berisi gambar fakta seputar masalah kesehatan reproduksi yang membuat siswa-siswi terkesima. Mereka menyatakan tidak pernah mengetahui dan melihatnya.

Setelah materi selesai disampaikan, banyak sekali siswa-siswi yang ingin mengajukan pertanyaan, namun karena keterbatasan waktu jumlah siswa yang ingin bertanya tidak dapat dipenuhi semuanya. Begitu pula dengan sesi tanya jawab, seluruh siswa-siswi dapat menjawab pertanyaan yang diberikan oleh nara sumber.

Hasil dari pengabdian ada dari beberapa mahasiswa yang berkeinginan untuk menjadi konselor remaja. Sehingga hasil tersebut merupakan tujuan dari terlaksananya pengabdian pada masyarakat. Koselor sebaya adalah anak remaja berasal dari sekolah (SMP/SMA/sederajat), karang taruna, poskestren, pemuda mesjid/gereja/keagamaan lainnya, pekerja industri, anak jalanan, dan lain-lain yang dilatih dengan materi tertentu sehingga mampu memberikan informasi dan ikut membantu menyelesaikan masalah kesehatan pada teman sebayanya. Apabila konselor sebaya menemukan masalah kesehatan, harus mampu merujuk masalah kesehatan tersebut ke fasilitas rujukan yang tersedia.

Berdasarkan hasil penelitian yang dilakukan oleh Lestary dan Sugiharti (2007) tentang perilaku berisiko remaja di Indonesia menurut Survey Kesehatan Reproduksi Remaja Indonesia (SKRRI), menyatakan bahwa perilaku berisiko pada remaja di Indonesia berhubungan signifikan dengan pengetahuan, sikap, umur, jenis kelamin, pendidikan, status ekonomi, akses terhadap media informasi, komunikasi dengan orang tua, dan adanya teman yang berprilaku berisiko.

Gambar 1. Penyampaian Materi pertama di MAN Dumai 


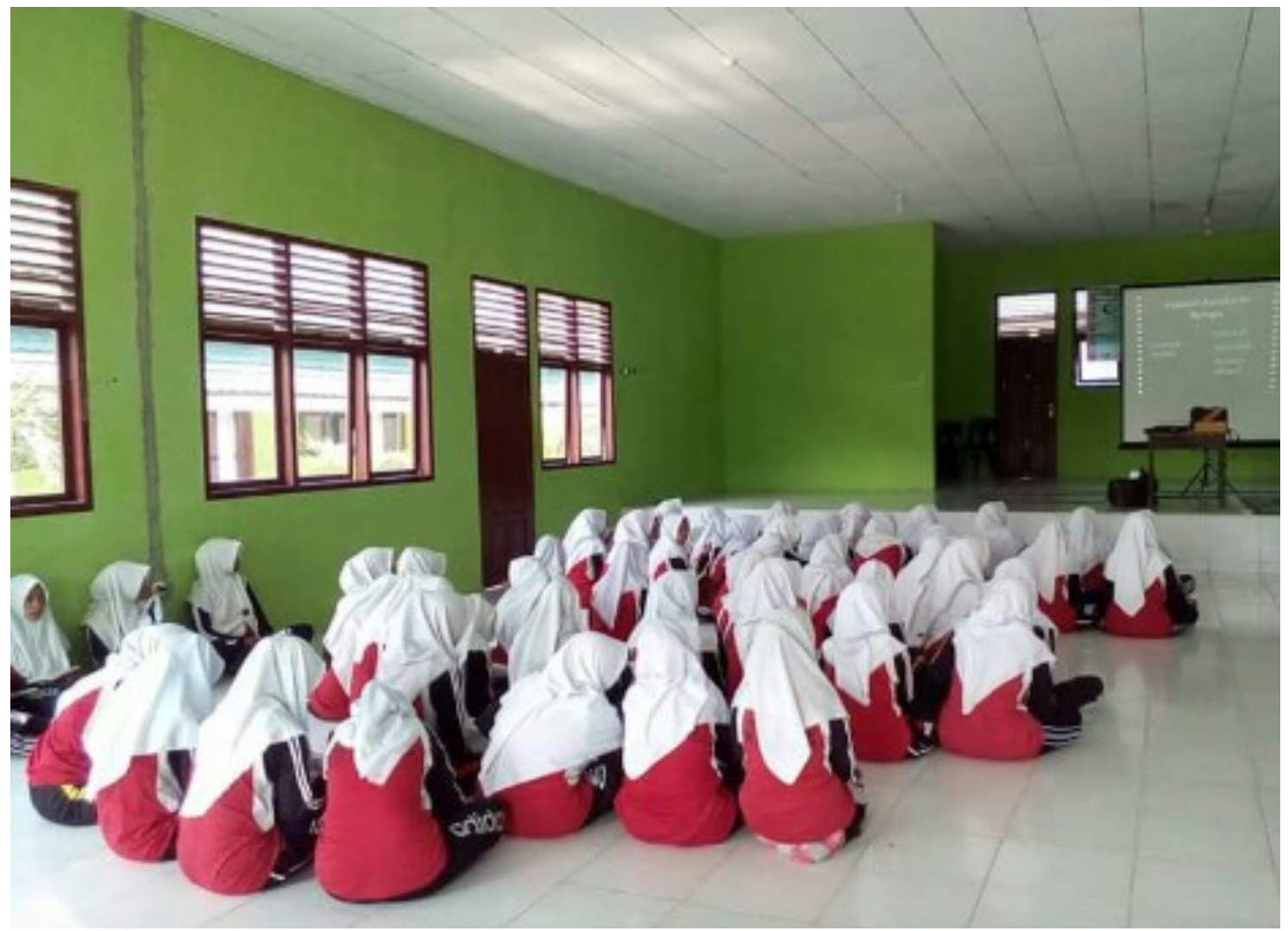

Gambar 2. Siswi MAN DUMAI

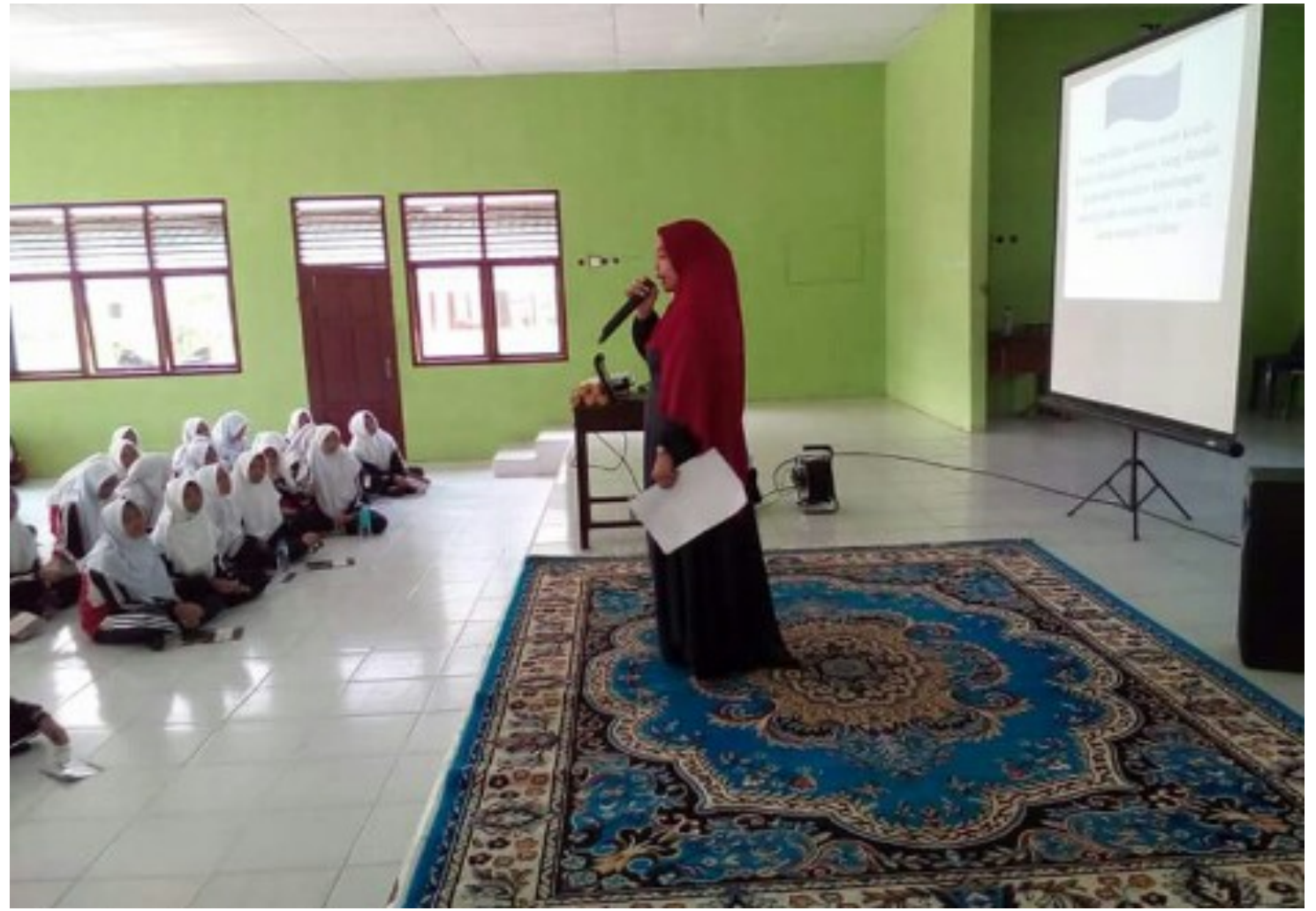

Gambar 3. Penyampaian Materi kedua di MAN Dumai 


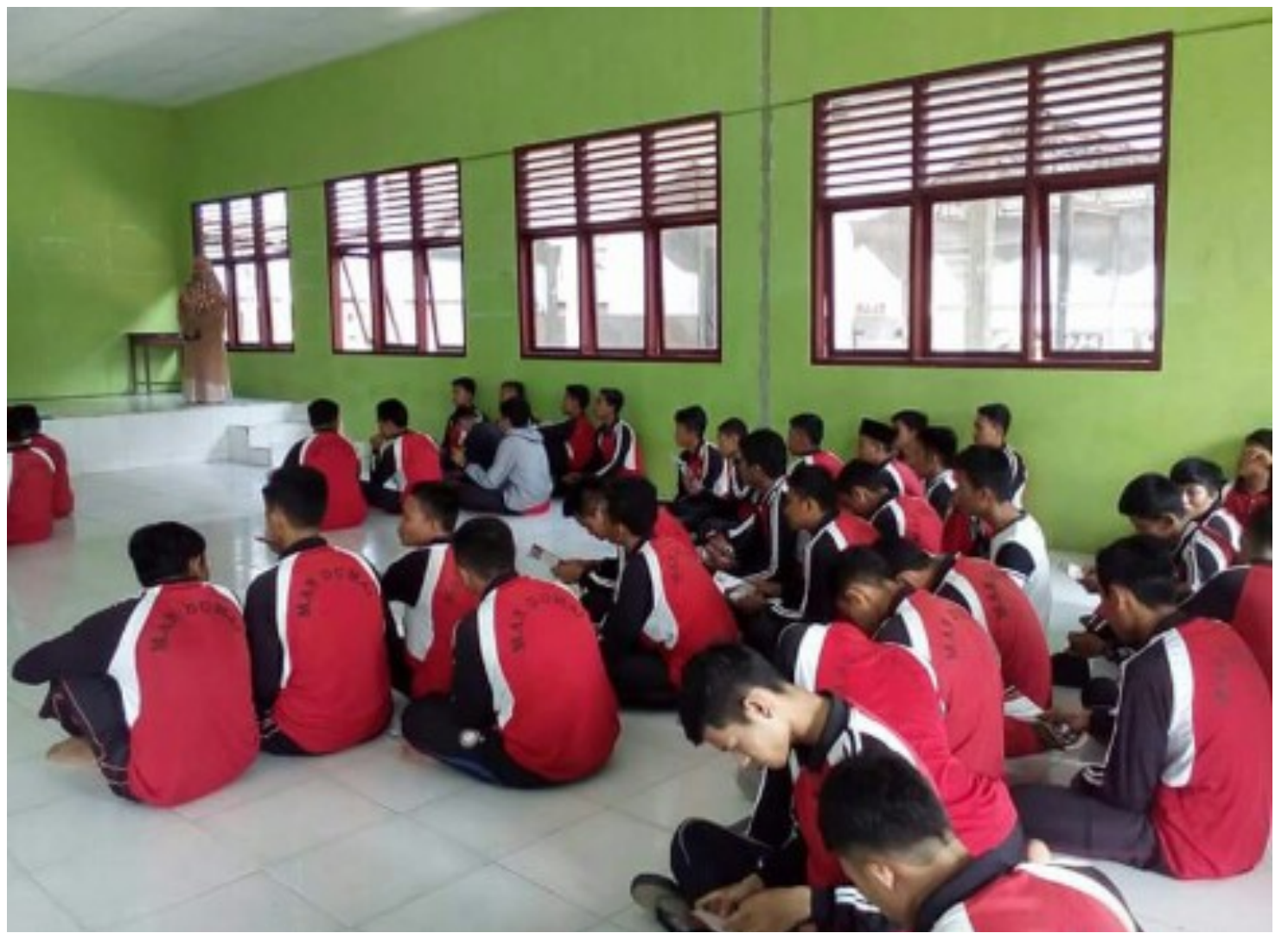

Gambar 4. Siswa MAN DUMAI

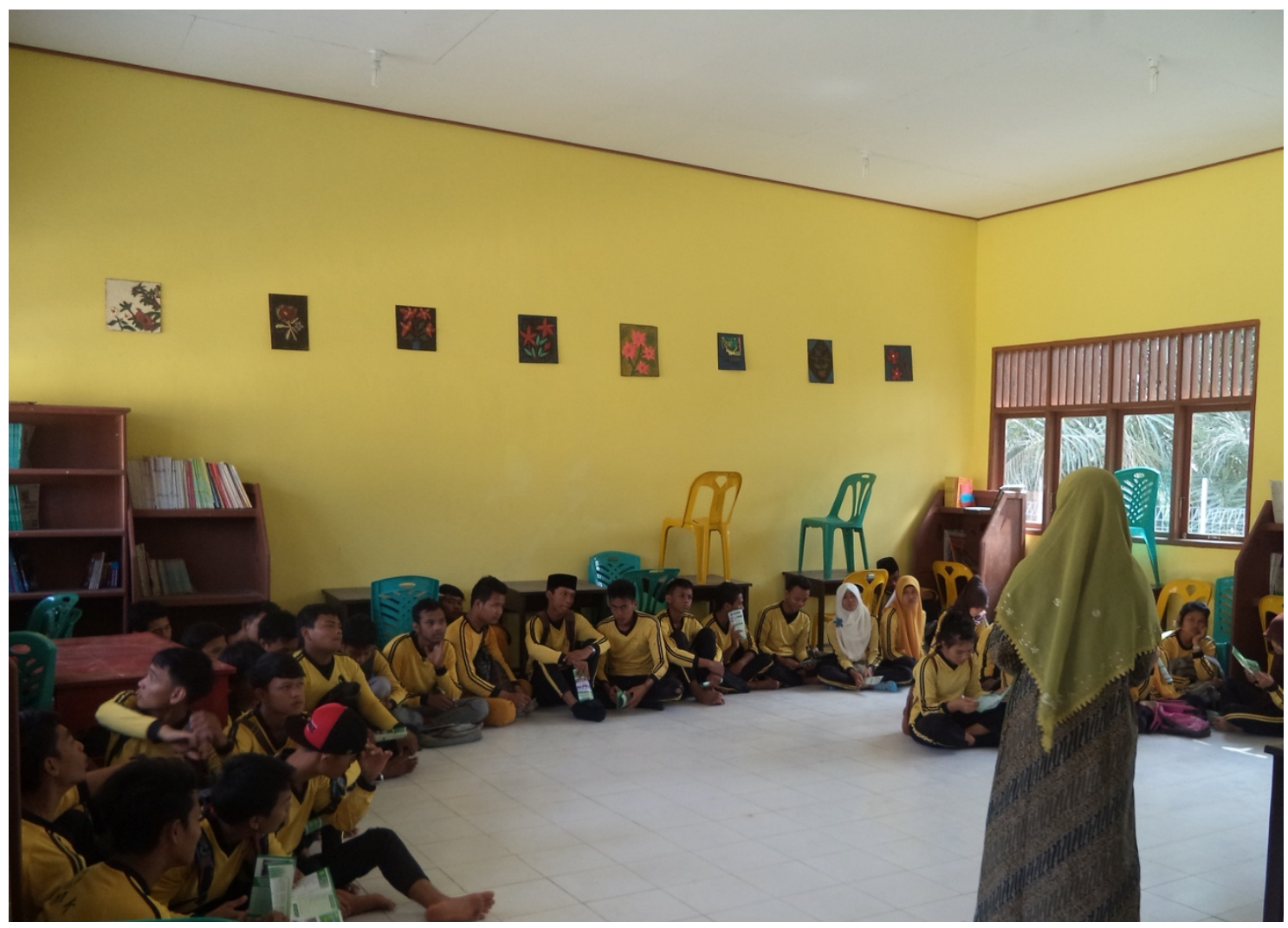

Gambar 5. Penyampaian Materi di SMKN 3 Dumai 


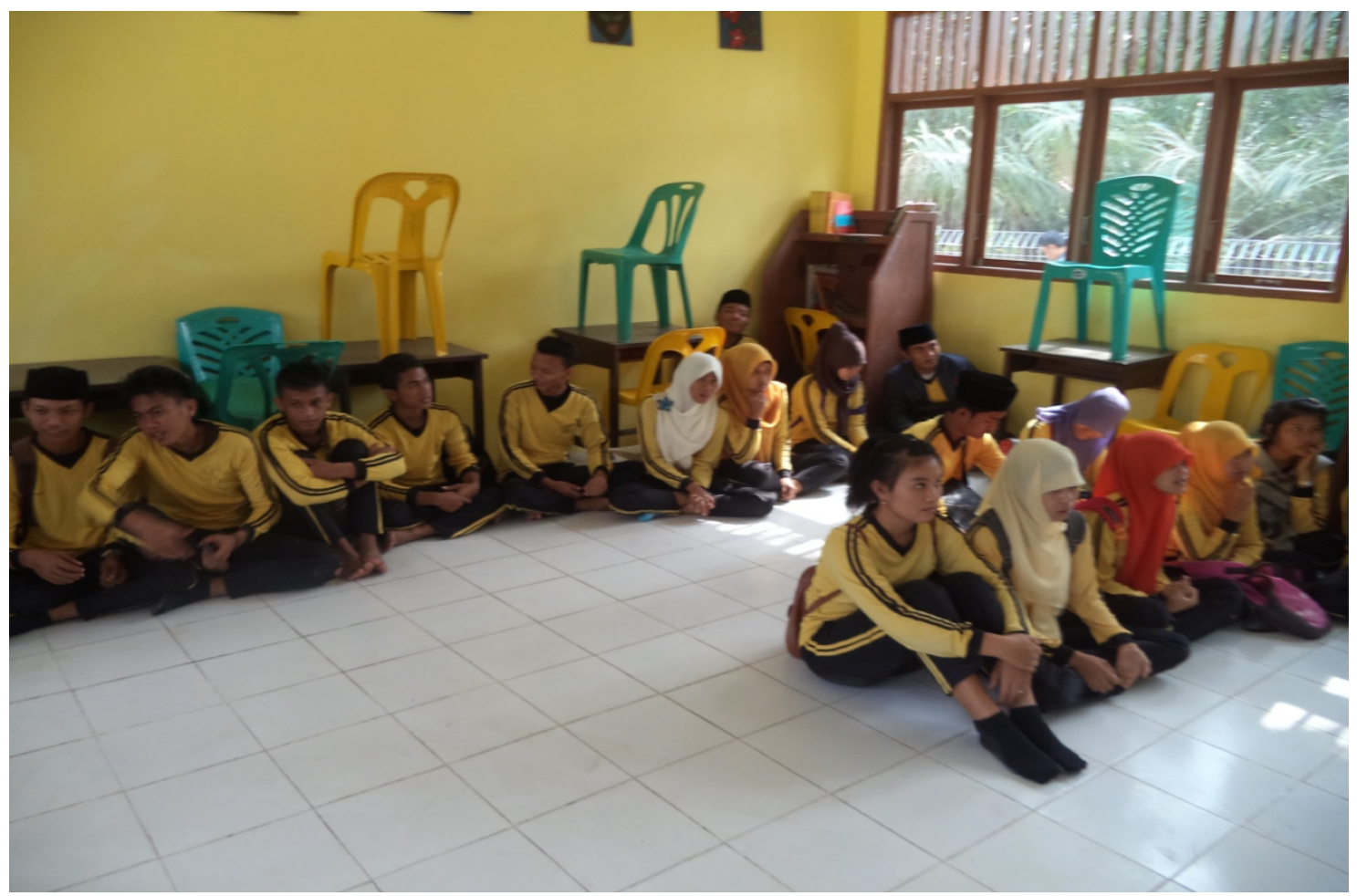

Gambar 6. Siswa-siswi yang mengikuti penyuluhan di SMKN 3 Dumai

Gambar 1 menunjukkan kegiatan penyuluhan di MAN Dumai yang disampaikan oleh Salmiati, SKM, M.Kes. Materi pertama yang disampaikan adalah tentang sex bebas, kehamilan tidak diinginkan (KTD) dan aborsi. Pada gambar 2 adalah saat menunggu kesediaan siswi yang ingin dijadikan konselor sebaya.

Gambar 3 menunjukkan kegiatan penyuluhan materi kedua yang disampaikan oleh Maria Arani, SST, M.Kes tentang merokok dan narkotika. Pada gambar 4 adalah saat menunggu kesediaan siswa yang ingin dijadikan konselor sebaya.

Gambar 5 dan 6 menunjukkan kegiatan penyuluhan di SMKN 3 Dumai yang disampaikan oleh Rini Hariani Ratih, SST, M.Kes. Pelaksanaan penyuluhan di SMKN 3 dilakukan di dalam kelas.

\section{KESIMPULAN}

Kehidupan remaja pada masa kini mulai memprihatinkan. Remaja yang seharusnya menjadi kader-kader penerus bangsa kini tidak bisa lagi menjadi jaminan untuk kemajuan Bangsa dan Negara. Bahkan banyak terjadi dekadensi moral. Dalam mewujudkan remaja sehat, salah satu upaya pemerintah adalah dengan pembentukan Program Pelayanan Kesehatan Peduli Remaja (PKPR).

Kegiatan dalam pengabdian ini diawali dengan melakukan penyuluhan serta kemudian melakukan pelatihan pendidik sebaya dan konselor sebaya. Kegiatan konselor sebaya dapat dilakukan karena ada siswa-siswi yang berkeinginan untuk dididik menjadi konselor sebaya. Namun pada akhirnya tidak ada satu pun siswa-siswi yang bersedia untuk dijadikan konselor sebaya. Dalam hal ini ada dari beberapa siswa-siswi di MAN dan SMKN 3 Dumai memiliki minat dalam menjadi konselor remaja. 
Terima kasih diucapkan kepada pihak sekolah MAN dan SMKN 3 Dumai yang telah memberi izin serta ikut membantu selama pelaksanaan penyuluhan berlangsung. Diharapkan kepada team pengabdian masyarakat selanjutnya untuk mempertimbangkan lagi dalam memilih sekolah sebagai sasaran pengabdian masyarakat. Hal ini dikarenakan untuk menghindari bertolak belakang antara mata pelajaran yang biasa dihadapi oleh siswa-siswi.

\section{DAFTAR PUSTAKA}

[1] Agustini, Ni Nyoman Mestri \& Arsani, Ni Luh Kadek Alit, "Remaja Sehat Melalui Pelayanan Kesehatan Peduli Remaja Di Tingkat Puskesmas.," $J$. Kesehat. Masy. Univ. Negeri Semarang, vol. ISSN 1858-, 2013.

[2] Depkes RI, Pedoman Pelayanan Kesehatan Peduli Remaja di Puskesmas. Direktorat Kesehatan Keluarga,. Jakarta: Dirjen Bina Kesehatan Masyarakat, 2008. 